\title{
Imagine being asked to evaluate your CEO ...: Using the constructive controversy approach to teach gender and management in times of economic crisis
}

Management Learning 20I5, Vol. 46(I) 6-23 (C) The Author(s) 2014

Reprints and permissions: sagepub.co.uk/journalsPermissions.nav DOI: $10.1177 / 13505076 / 4549119$ mlq.sagepub.com

@SAGE

\section{Silvia Gherardi and Annalisa Murgia}

University of Trento, Italy

\begin{abstract}
This article addresses the relationship between gender and management as intertwined discursive practices. Following a constructive controversial approach, we proposed to the students to complete a short story in which they have to give a feedback either to a fictitious female or to a male boss. The article has a dual aim since it offers a reflection on a teaching methodology suited to foster critical thinking in the classroom and analyzes the narratives so produced in search of what constitutes the students' idea of "good management." In positioning men/women CEO within a narrative, students enact a moral order that evaluates management in society. Their narratives reveal how the economic crisis has undermined the positive image of the male manager, while femaleness is emphasized for its anti-managerial imaginary. Moreover, the idea of what constitutes "good management" is constructed around an idea of care for both male and female CEOs.
\end{abstract}

\section{Keywords}

Constructive controversial approach, gendering management, moral order, positioning theory

\section{Introduction}

Management has long been a controversial topic in critical organizational studies because of its importance in constructing and legitimizing dominant discourses and scenarios (Alvesson and Deetz, 2000; Alvesson et al., 2009; Grey and Willmott, 2005), and the gendering of management has been historically constructed as a male subtext by producing imageries which are difficult to relate to femaleness (Ashcraft, 2011; Collinson and Hearn, 1994; Knights and Kerfoot, 2004). Furthermore, textbooks on management and entrepreneurship have been criticized for assuming a taken-for-granted gender bias toward the male body and masculinity, and introducing open discussion on the topic in the classroom is difficult because language and power interact to keep masculinity invisible and undiscussable. 
Within such a cultural scenario, we want to open discussion on teaching methodologies. In fact, how to teach gender and management has been the focus of reflection in recent years. Pedagogical orientations have ranged from "women in management," which helps women to reflect on their experiences in organizations, through diversity management, which clarifies how political and discursive processes construct gender differences and sexual identities, to an approach to men and masculinities that focuses on how organizations are sites for the construction of management and masculinities. Nevertheless, teaching gender and management is still problematic, whether the audience consists of students or managers. The fact is that both the discourses on gender and management are highly ideologized and tend to reproduce an androcentric imagery that makes hegemonic masculinity invisible (Fletcher, 2004). This should be recognized before any broad discussion is possible, especially if, as teachers, we ask how it is possible to teach without acritically reproducing such assumptions and simultaneously without indoctrinating the students.

Critical feminist scholars have challenged the ideology and the legitimacy of management by naming "men as men" in order to show the gender subtext in management (Martin, 1996). They have examined issues of power and resistance (Calás and Smircich, 2009) and gendered and ethnocentric constructions of management in management teaching (Kelan, 2013; Sinclair, 2000). Overall, the aim of critical feminist research is to challenge what is taken for granted in social relations and to demonstrate the problematic nature of the status quo, its apparent naturalness, and inevitability.

We adopt a critical feminist approach to teach the interplay between gender and management. Together with a group of students, we tried out a methodology based on the "constructive controversy case study" (Bird and Erickson, 2010) and intended to foster critical reflection on multiple perspectives and ethical issues.

We shall describe this methodology more thoroughly in the research design section. For the time being, we anticipate that its purpose is to encourage discussion of controversial issues. In fact, in real-life situations, students (like everybody else) find that the ideological differences that separate them from others are much less clear-cut than those presented in textbooks or anticipated by the participants in the discussion. A "constructive controversy approach" is designed to capture the complexities of social interactions that defy simple solutions. It can therefore open a space for the discussion of gender relations in management starting from the students' experiences and beliefs, instead of introducing the topic "top down." Creating an open classroom where students can voice doubts and expose vulnerabilities is hard, time-consuming, and anxiety-provoking for both teachers and students (Short et al., 1996; Sinclair, 2000). Working with stereotypes is difficult, even when the students are the authors of the stories that they analyze when engaging with gender issues. Preconceptions are strong and are not easy to discuss openly. Nevertheless, when students (or managers) are given the chance to conduct such discussion methodically, the learning potential is very high.

As a starting point for the development of a "constructive controversial case study," we invited the students to complete a short story in which they imagined they were evaluating either a female or a male CEO. We proposed a stimulus text whose ending was to be completed by the students. In writing their narratives, the students performed their implicit and explicit understanding of gender and power in the context of managerial activities (Brown et al., 2009). At the same time, in their use of language and in the way the plot of their narratives was constructed, we can ground an analysis of how the discourse on management is mobilized, accepted, and contested.

Our contribution to the literature on teaching and learning gender and management is to illustrate the potential of the constructive controversy approach, which relates to both an opportunity for individual experiential learning and its generative learning context. In other words, the students are invited to reflect on how gender is embedded in the stories they narrate, and the effect thus produced. At the same time, they learn what the discourse on management "does" and what kind of moral order it expresses. 
This article conducts a dual reading of the students' stories. On the one hand, it proposes a methodological reflection on the pedagogic potential of a teaching method which elicits the direct expression of implicit assumptions concerning controversial issues. In this case, stories are analyzed for what they do in the classroom context, and they furnish material that can be transferred to other audiences. On the other hand, when the stories are read as texts, the focus of the article is on the expression of culturally and historically situated assumptions which illustrate the collective imagery of controversial issues and the moral order that they express. The intent of the latter reading is to contribute to the recent trend in the literature (Kociatkiewicz and Kostera, 2012) that reflects on what constitutes a morally sustainable managerial style and on how our own scholarship contributes to its narrative construction.

This article is organized into five sections. First, we sketch the reasons for approaching gender and management as controversial issues. Then, we introduce positioning theory as the theoretical framework that enabled us to draw up our research design. In the fourth section, after describing the methodological steps used in our analysis of the students' narratives, we present the results. The students' narratives are read - and presented - as follows: how the students positioned their narrating selves vis-à-vis management, how they positioned their texts in the context of the economic crisis, how in their texts the ideal of "good manager" is gendered, and finally, what they believed makes management "good." Finally, conclusions are drawn in the fifth section.

\section{Positioning gender and management as controversial issues}

A critical feminist reading of gender and management shows how they are discursively constructed to maintain and reinforce hegemonic masculinity (Connell, 1987). Textual representations of masculinities and of patriarchal paternalism appear to be rooted in the way that the manager's action is described. However, the meaning of management and the meaning of gender are never defined because their symbolic orders are cultural, historical, and situated products performed by cultural practices (Calás et al., 2014).

We shall assume a theoretical stance on gender that treats it as socially constructed, as a situated performance, and as social practice (Martin, 2006; Poggio, 2006); our reading of gender in narratives about management will use positionality theory (Alcoff, 1988; Davies and Harré, 1990). According to the positioning approach, gender and management can be analyzed in a highly dynamic way as intertwined, relational, and discursive practices (Katila and Eriksson, 2013), as well as controversial issues on which diverse discourses converge and conflict.

The concept of positionality originated in gender studies (Alcoff, 1988; Gherardi, 1995; Davies and Harré, 1990). In particular, the approach termed positioning analysis concentrates on how the subjects situate themselves in the story (in this case the written text) and how they allocate the parts to the characters, including both the position of the narrator (subject position) and that of the actors (or objects) to which the story is addressed, using the cultural repertoires available.

In a written narrative, the discursive positioning of the narrating self indicates how the subjectivity of the writer is constructed within the moral order of his or her discourse. A subject position is what is created in and through conversations as speakers (or writers) and hearers (or readers) construct themselves as persons: it creates a location in which social relations and actions are mediated by symbolic forms and modes of being. As people assume a discursive positioning for themselves, they also attribute - explicitly or implicitly-discursive positions to possible audiences and to objects of discourse. Positioning theory is therefore useful for analysis of the discursive production of self and the topics narrated as a linguistic practice. The topics of gender and management are positioned in students' narratives through discourses, practices, norms, languages, and values which reflect the socially constructed images of maleness and 
femaleness (Kelan, 2009a; Martin and Meyerson, 1997; Sinclair, 2005) and the moral order sustaining them.

In fact, moral order is a central dimension of culture. The term refers to any system of obligations that defines what are the proper relations - good, right, virtuous - among individuals and groups in a community. Such systems of moral belief are kept within religions, traditions, or ideologies. According to Douglas (1975), the dimension of moral order goes deeper than beliefs about mutual obligation since she conceives order as how we assign and keep things in their place and how we react to things that we see as being out of place. Therefore, when we analyze the students' narratives, we shall see how, by putting gender and management "in their right places," a narrative expresses an implicit idea of "good management" grounded in a situated moral order.

While the concept of moral order is well established in cultural studies and the concerns that it expresses are mainly related to values and cultural elaboration of ethical codes, within the so-called "French pragmatism" (or "sociology of convention"), the concerns are related to discursive justification of what is conceived as "common good."

The roots of French pragmatism are found in explanations of the nature of the social situation within which actors interact and of how they carry out different types of "justification work" (Boltanski and Thévenot, 2000). In their publication On Justification (Boltanski and Thévenot, 2006 [1991]), the authors focus on the dynamics and contents of justifications when controversies arise and are publicly discussed, and where a "sense of justice" is meant (Dodier, 1993; Pernkopf-Konhäusner, 2014 ) in actors' social competence. The competence of the actor is about realizing joint activities, but with reference to higher moral order standards, so that what they perform is a joint action toward the common good. Even outside the public arena, actors engage in continuous interpretation or "justification work" (Jagd, 2011), question previous conclusions, and establish "local ordering" (Dodier, 1993: 563). In such circumstances, actors find new ways to handle unclear circumstances and invent conventions (Diaz-Bone, 2011). A symbolic work is involved in developing justifications that actors provide rationales consistent with socially accepted definitions of the common good, they are actively engaged with competing definitions of the common good held by different social groups, and the development of effective justifications in such contexts requires specific competencies with regard to the construction of convincing accounts and arguments (Patriotta et al., 2011)

Boltanski and Thévenot's theory acknowledges the existence of a plurality of orders of worth that cut across social worlds and organizational fields, and it allows to take into account the discursive competence of actors in mobilizing and combining orders of worth for the purpose of gaining legitimacy. It allows exploring the process whereby orders of worth are negotiated and tested.

In this sense, students' narratives are interesting cultural products that not only reflect their socially constructed moral order in relation to two controversial topics, namely, management and gender, but also allow the analysis of the justification work deployed when what is conceived as "common good" is affirmed, contested, and negotiated in controversial situations.

\section{The study design}

The term "constructive controversy case study" "refers to brief story-like scenarios that are informed by sociological theories and concepts and are based on actual research findings" (Bird and Erickson, 2010: 120). Bird and Erickson used the term "constructive controversy case study" because they were reflecting on the construction and use of non-traditional case studies in teaching about inequalities. In their case study called "Drinks and Dinner," and constructed using empirical research findings from Martin $(2001,2003)$, they asked the students to discuss the intentional ambiguities written in the case study while incorporating, honoring, and addressing the differences of opinion not only among the characters in the story but also among the students in the classroom. 
Their aim was to induce the students, actively and collectively, to address and solve problems related to inequality and the routine use of power.

A constructive controversy case study has the following objectives: (a) to encourage students to consider multiple perspectives on a complex series of social interactions, (b) to support them in developing an original interpretation of the case while honoring and incorporating differences of opinion, and (c) to engage students in active problem solving in the context of life experience.

While we share the aims of Bird and Erickson's method and we are equally interested in developing non-traditional experiments in teaching, we think that their model is not so easy to use since the requirement of grounding the case study on actual research findings constitutes an unintended limitation that may be overcome, and this article shows in which direction this may be done. Moreover, the meaning of what constitutes a "case study" is rather narrow, and it may be enlarged as well.

Differently from Bird and Erickson, we prefer to name our teaching method the "constructive controversy approach." While Bird and Erickson proposed to their students a case study using empirical research findings, we preferred to elicit production by the students of written texts and to arrange the constructive controversies starting from the analysis of their narratives, rather than presenting them with a teacher-constructed case study. The reason for innovating on Bird and Erickson's method was that Gherardi - one of the two authors - has had previous experience of using the constructive controversy case study in teaching gender on doctoral courses and wanted to explore its potential further. In fact, we thought that the use of students' texts has several advantages. It engages the students in their own cultural products through their own language use, and this device would help us counter the criticism of case studies that they are non-realistic or outdated. It was also an opportunity to teach the students how to conduct a discourse analysis driven by positionality.

In our teaching experiment, we gratefully encountered the example of Katila and Eriksson (2013) who have been working with Finnish students' representations of gender and management, and we decided to adopt their stimulus text methodology to elicit our students' controversial narratives. The stimulus text (Bauer and Gaskell, 2000) is an elicitation technique used in interviews where the respondents are asked to interpret pictures or to write stories about them, to draw pictures, to play a part in or to produce metaphors describing a situation, to complete sentences, to develop collages, to discuss movies, and so on (Törrönen, 2002).

The field study was conducted in 2011 in two classes taught by the two authors. It was carried out during two lectures in each of the classes. The students of the first and second years of the Master course in sociology "Work, Organization, and Information Systems" of the University of Trento (Italy) were asked to volunteer ${ }^{1}$ to write a short story during a two-hour session. All the students (28 women and 15 men) agreed to take part in what was presented to them as an experimental project to introduce the lesson of the following week. They had 30 minutes to complete the story, and the average length of a story was less than a page. During the first lesson, after the students had written their stories, they were taught the basic elements of discourse analysis. During the second lesson, we introduced the constructive controversial case study based on their stories and our analysis of their stories.

In the first lesson, we gave the participants a stimulus text whose story line they were asked to complete and we gave them instructions as well. Two different versions of the stimulus text were used. Each student received only one version, with a fictitious male or female CEO, Diana or Davide Tomasi. They did not know that two versions of the story had been given out. We used the same text as previously used by Katila and Eriksson (2013: 74-75) with their Finnish business school students.

The text given to the students was as follows: 
Imagine that you are an employee of a company called Alfa Co. For the past year, your supervisor, Diana/ Davide Tomasi, has been the CEO of the company. S/he is also chair of the board and in charge of, among other things, the company's strategic management. It is time for the annual organizational climate survey. As in previous years, all the feedback that you give will remain anonymous and, therefore, impossible to trace back to you. You have already filled in the climate questionnaire. You now receive a blank piece of paper and are asked to give feedback on the performance of your new CEO. The idea sounds good-for once you can express your thoughts and feelings in your own words.

You start thinking about the eventful history of the previous year ...

The instructions for completing the story were described in the following sentence:

Your task is to try and relate to the situation and evaluate how successful your new CEO, Diana/Davide Tomasi, has been during the year. Give a detailed description of the kind of manager you perceive her/him to be. Thinking about events in which s/he has participated might help you complete your story.

We collected 43 stories, and the sex distribution of authorship roughly reflected the composition by sex of the sociology students in our department: 22 stories were written about a female CEO (18 by women and four by men) and 21 stories were written about a male CEO (10 by women and 11 by men). A limitation in our research design may derive from the fact that the stories written by women on Diana were overrepresented.

It is opportune to give an idea of who the writers were. In the coding system of the quotes that we are about to use, we report the number of the story, use the symbol $\mathrm{M}$ for a male author and $\mathrm{W}$ for a female one, and state the student's course year. Although we always allow the reader to know the author's gender, we shall not take it into account when analyzing the stories since we opted for a discursive analysis of how gender is positioned in the text.

\section{Text analysis for the construction of the controversial case study}

We conducted the text analysis between the first and the second lesson and constructed a controversial case study based on the students' own narratives. The first stage of analysis enabled us to determine the extent to which the stories respected the initial instructions: whether they were expressing an evaluation ("how successful your new CEO was") in relation to "the kind of manager you perceive him/her to be." With this first screening, we verified the adherence of the stories to the aim of the research (did the stories express an idea of the "good manager"? and was management described in a way that portrayed the moral order of the narrator?). At this stage of the analysis, we read all the stories in order to identify how the narrator was positioning himself or herself with respect to the CEO. We tried to understand whether he or she was talking from a sympathetic position, a critical one, a neutral one, or one somewhere in between. In doing so, we also identified whether the narrator was positioning himself or herself as an individual actor or as part of a collective one.

In the second stage of analysis, we identified the events being talked about, the context in which those events took place, and took note of other complicating events or situations presented in the stories in order to gather evidence of proximity and similarity or distance and difference from the managerial character. We then introduced the gender of the CEO in order to see how the gendering of managerial practices was discursively accomplished. Finally, we focused on the moral order of the whole story (see Table 1) since this would enable us to situate the main question of positioning theory about what a story "does" in the context of its being told (written in our case). 
Table I. Methodology for the analysis of the narratives and construction of the controversial case study.

\begin{tabular}{lll}
\hline $\begin{array}{l}\text { Steps in the students' discursive } \\
\text { analysis of their narratives }\end{array}$ & $\begin{array}{l}\text { Rationale for the choice of texts to } \\
\text { be discussed in class }\end{array}$ & $\begin{array}{l}\text { Controversial issues for } \\
\text { discussion }\end{array}$ \\
\hline $\begin{array}{l}\text { How is the subject position } \\
\text { constructed? }\end{array}$ & $\begin{array}{l}\text { The subject position is constructed } \\
\text { as that of an individual or collective } \\
\text { actor } \\
\text { The subject position is constructed } \\
\text { as having interests in common } \\
\text { with or antagonistic to those of } \\
\text { management }\end{array}$ & $\begin{array}{l}\text { Management: common or } \\
\text { antagonistic interests? }\end{array}$ \\
How is the context positioned? & $\begin{array}{l}\text { The economic crisis as the main } \\
\text { descriptor of the context }\end{array}$ & $\begin{array}{l}\text { Economic crisis and managerial } \\
\text { responsibility }\end{array}$ \\
Mow is the CEO gendered? & $\begin{array}{l}\text { Management of the crisis and } \\
\text { Pondering of the CEO } \\
\text { to stereotypical gender attributions } \\
\text { Positioning the "ideal manager" }\end{array}$ & $\begin{array}{l}\text { The gendering of managerial } \\
\text { practices }\end{array}$ \\
What makes "good & $\begin{array}{l}\text { The moral order expressed by the } \\
\text { evaluation of the CEO }\end{array}$ & $\begin{array}{l}\text { The "good" of the company or } \\
\text { the "good" of the people in it? }\end{array}$ \\
management" good? & &
\end{tabular}

In order to be more rigorous in our text analysis, we used the ATLAS.ti software program, which enabled us to identify the common emergent themes systematically. On this basis, we chose excerpts representing controversial issues that, in our opinion, were best suited to initiating class discussion and that we illustrate in the next section.

\section{Working in the classroom}

In the classroom, during the second lesson, the students analyzed their own stories according to the same four questions that we used in our text analysis: How is the subject position constructed? How is the context positioned? How is the CEO gendered? What makes "good management" good? In this way, they learnt how to approach a text and conduct a discursive analysis informed by positioning theory. Discourse analysis was presented as focusing "on talk and texts as social practices and on the resources that are drawn on to enable those practices" (Potter, 1996: 129). In fact, discourse analysis allows exploration of the subject's positioning in a given context and of how reality is discursively constructed in relation to the positioning of others (people or things) and the audience.

Our text analysis was brought for discussion in the class. The material was organized around the main controversial issues that we identified in order to prompt debate on how the students' stories reflected their different understandings of the relationship between gender and management and how their conception of "good management" was discursively accomplished.

Table 1 summarizes the steps that we followed in proposing the analysis of the narratives to the students, how we chose some excerpts from their texts, and how we selected the controversial issues proposed for discussion.

\section{Presenting four constructive controversies}

The next sections illustrate the four controversies open for discussion: (a) management: common or antagonistic interests, (b) economic crisis and managerial responsibility, (c) the gendering of managerial practices, and (d) for the good of the company or of the people in it? 


\section{Management: common or antagonistic interests?}

In a narrative, the discursive positioning of the narrating self indicates how the writer's subject position is constructed and from which standpoint the story is told. While some of the students' narratives assumed an individual standpoint, many others were written from a collective point of view - that of "us" employees or workers - and they mainly constructed the narrating self as antagonistic to management:

I would like to express my criticism of the CEO Davide Tomasi and his behaviour in the company. [...] I believe that most of my colleagues are aware of this situation. If I must express an opinion on the results obtained, I think that Tomasi has caused great damage to this company. The only good things have been done by ignoring his orders and acting according to our own abilities. We would certainly all benefit from Mr Tomasi's removal as CEO. (Story 9_M_first year)

I saw immediately that Tomasi was someone aiming very high. A few years later he is already right up there, with us down here slaving away and looking at him with his double-breasted suits and black leather shoes. Always on the go, always agitated, sooner or later he's going to fall ill — too much stress, you see. Too much stress, which he makes us employees pay for: his cock-ups because he is in a hurry, and the excessive delegation, why has the board of directors let him delegate so much? (Story 16_M_ first year)

We chose the above two vignettes and we asked the students to discuss them in relation to another story in which the subject position is discursively constructed within a context of shared interests within the company:

Diana Tomasi, she is our company's CEO. I say "our" because I feel that I'm an integral part of this great organization, and this is certainly also due to her. During this year as well, she has managed to organize several occasions for us to exchange opinions and points of view. (Story 30_W_second year)

This comparison allowed discussion on the interests of the company, the management, and employees as antagonistic or shared. The controversial issues up for discussion concerned the positioning of the author-individual or collective - and the relationship with managers - cooperative or antagonistic - within class interests. The students also began to see how Diana received a more positive judgment than Davide and how this was positivity tied to participation.

Because the scenario constructed by the stimulus text was one that elicited ethical and personal opinions, it evidenced how the moral order expressed by the first two vignettes constructed management as pursuing interests in conflict with those of its subordinates, while a commonality of interests was expressed in the second one. The issue was left open for the next controversies discussed during the lesson.

In conclusion, analysis of a text following the question "how the narrative self is constructed" was the first step that we asked the students to do on their own narratives, before proposing the discussion of the three vignettes that led to debate on power, interests, and management.

\section{Economic crisis and managerial responsibility}

The students' narratives gave access to the ways in which they actively reproduced the historical and cultural context in which they wrote their stories. We shall now see how Davide or Diana was positioned against the background of the recent economic crisis. This point was important in constructing a controversial issue because the crisis was not simply the context of the stories but an 
element mobilized to gender the crisis itself and to discuss masculinity in relation to it. Before presenting the extracts we used in the classroom on this point, we shall briefly recall the magnitude of the crisis in Italy in order to explain why the students were so concerned about it.

In Italy, as in most Western countries, the recent financial crisis has exacerbated the structural problems relative to youth employment, especially in terms of quality of work and female participation in the labor market. In fact, although there has been a significant increase in women's education and labor-market participation (Vinnicombe, 2000), their access to specific occupations, and especially to managerial and executive roles, is still problematic (Murgia and Poggio, 2011; Bombelli, 2000). The careers of highly educated women who can — and should — aspire to management positions continue to be characterized not only by the increased presence of over-qualification but also by episodes of discontinuity and by a considerable wage gap. In Italy, the managerial culture is largely dominated by masculinity and vertical segregation (Murgia and Poggio, 2014; Bombelli, 2000 ) in both the economy and politics, even if a certain feminization of occupations and high positions in the bureaucracy is becoming apparent. Therefore, the Italian situation of female participation in work and social life is distant from that of other European countries or the United States. Awareness of this situation was high among the students, also because these topics were part of their curriculum.

The crisis discourse was positioned in terms of Davide, who mobilized it in order to justify staff cutbacks, no substitutes for staff on maternity leave, and increased workloads for the employees remaining at work:

He says that there's no money to hire someone here in my office, that there's a crisis, but here we make thirty percent of the turnover of the whole shebang. He ought to understand that we need someone. Now that Carla and Giulia are on maternity leave and Andrea has retired, there are only two of us left to do work that we used to do in five. He says that he has to look at the balance sheet. But without investments it will always be a struggle for survival and what is hiring by a service firm if not an investment? (Story 16_M first year_Davide)

The economic crisis was gendered differently in regard to Diana. In fact, she was positioned as worried and as committed to saving the budget:

Obviously, as everyone knows, this has been a difficult year, there have been staff cuts and I've noticed she too was worried and focused on keeping the company budget balanced. (Story 30_W_second year_Diana)

It is thus in the economic context itself and the current phase of the economic crisis - particularly acute and worrying in Italy - that the managers were positioned in the stories. The positioning was not limited to the expertise of the $\mathrm{CEO}$, but reflected the critical position of the narrators in relation to an overall economic situation causing concern. The controversial issue debated in relation to the ambiguity of the crisis as a managerial rhetoric versus a challenge for the manager was also framed in terms of a caring attitude attributed to Diana versus a disregard of the crisis by Davide, whose attitude was disapproved not only because it was unable to deal with the recession but also because it was a sign of misconceived masculinity.

To be emphasized is how, in the negative evaluation of managerial performance at a time of economic crisis, the gendering of management expressed distrust in management and in the image of the manager as a traditional "male hero." The association among crisis, masculinity, and management was debated by the students in relation to both the issue of management responsibility and the idea of good management associated with gendering practices - as we shall see in the next section. In fact, the debate in the class was an ongoing process that is presented here in separate 
steps for writing reasons but should be imagined as a process of growing complexity where all the controversial issues appeared interconnected.

In summary, the second step in teaching how to conduct a discursive analysis was inviting the students to answer the question "what is the context of the story and how is it constructed?" Since many stories delineated a context of economic difficulty for the company Alfa, associated with criticism of Davide's bad management, we proposed discussion of the above vignettes in order to initiate debate on the contexts described and on managerial responsibility.

\section{The gendering of managerial practices}

When Davide and Diana were constructed as positive characters, were they attributed the same skills and attitudes? How was the gendering of management done discursively? As emphasized by other studies that have investigated how managerial positionings are gender-typed (Atwater et al., 2004), managerial practices may be prototyped as masculine or feminine. Decisiveness, for instance, has been traditionally considered part of a masculine stereotype, while being helpful and sympathetic is part of a traditionally feminine stereotype.

On first analysis, we found this type of gender positioning also in the stories written by the students. Davide was described as an authoritarian interested only in organizational efficiency and indifferent to the needs of the workers. By contrast, Diana was described as attentive to involvement of the personnel and ready to listen to the employees:

Even if someone wants to report things that are not working in the company, they are held back by a sort of fear, given the power of Davide Tomasi. Fear of being sacked if you are wrong ... of losing a job that you don't like very much ... but is more than alright at a time of crisis ... A sort of relationship between manager and employee that you know ... is biased towards the manager. A manager who, instead of improving the organizational climate by listening to and helping his employees, thinks only to efficiency targets. (Story 19_W_first years)

In the year just passed, the organizational climate has been good, thanks to the efforts of the general manager Diana Tomasi. In order to monitor the relational climate, every month Tomasi has held meetings with every section, from production to administration. During these meetings the manager has devoted an hour to describing the company's performance so that we would not feel entirely extraneous to the decisions taken by the administration. The second hour was devoted to listening to the employees' problems. (Story 32_W_second years)

In the former case, distrust in Davide was expressed because he was only interested in efficiency and unable to listen to employees, flaunting his position of power. In the latter case, Diana was a manager with organizational and relational skills, able to communicate with employees and to form a team. The gendering of Davide and Diana's managerial practice was done along the symbolic dimensions of masculinity (instrumentality) versus femininity (care), but instrumentality was evaluated in negative terms. In contrast with a traditional conception of "think manager-think male" (Schein, 2007) that privileges masculinity in management, the students' narratives expressed strong distrust in traditional forms of man/agement. More examples follow.

Another interesting difference between the positionings of Davide and Diana in the stories collected in the classroom concerned the capacity of innovation attributed to male or female CEOs:

I also believe that Tomasi is uninterested in innovation: when I or my colleagues make new proposals or ones out of the ordinary, he either ignores them or sneers at them. This devalues our attempts to furnish quality services which meet the specific needs of our customers. (Story 3 _W_first years) 
Over the years, in fact, she has been the main promoter of certain innovative initiatives in this respect, which have actually remained on standby for a long period because they were not well seen by the former CEO, an "old fashioned" man, tied to rigid schemes of work organization. (Story 5_W_first year)

When we tried in the classroom to identify the initiatives cited in support of the positive assessment given to Diana, we found an argument that highlighted and itemized the elements that can constitute the well-being of employees. Diana was evaluated positively not only when she showed relational skills but also when she ran the firm efficiently, especially in terms of workplace safety, training, and relationships with the trade unions:

In my assessment I reason both objectively and subjectively; objectively on how the CEO [Diana] has acted to address issues concerning the employees and thereby relations with the union representatives; investment in safety and training; and the role of leadership, sometimes adopted, sometimes not, in situations of uncertainty, for example during a period in which there were organizational problems on certain production lines. Also very important is the acceptance or rejection of dialogue with the various parties involved, regardless of their positions within the hierarchy. Moving from the objective to the subjective perspective, I tend to rely more on my feelings, that is to say, the sense of trust that the CEO inspires in me, also in situations in which I have had direct contact with her, when I have had to ask for advice on problems relating to both my work and other aspects within or outside work. (Story 25_M second year)

The narrator of this story was a man who positioned himself as a close colleague of Diana and as an "objective" narrator who, in his assessment, adopted both objective criteria, which he expressed first, and subjective ones. He thus founded his authority on his competence in the multiple use of assessment criteria and on the subordination of subjectivity to objectivity. This rhetorical strategy enabled the narrator to reinforce the positioning of his narrating self as someone who felt a sense of trust and thus as someone who "objectively," and for good reasons related to the company management (relations with workers and unions, safety, training, and leadership style), could rely on the management.

Most of the narratives positioned Davide and Diana according to traditional gender stereotypes, attributing distrust to Davide and hope to Diana. Nevertheless, a third positioning that did not follow gender stereotyping became visible when Davide was valued in positive terms.

The (few) male CEOs positioned in the stories as completely positive figures were able not only to manage the company budget and to focus on "productivity growth" but also to create a positive working environment and to "accept advice" from employees. Among the positive judgments, what the stories highlighted is that relational skills are of much greater extent:

At work he is polite to all of us and he tries to treat us all equally without showing any partiality. I really appreciate it when he accepts our advice, even the most disparate ones that cannot have any positive outcome [...] I regard him as intelligent because he has been able to reduce the friction among Italian workers and foreign workers within the company, friction that began three years ago and created several problems and a decline in productivity. By solving this problem, the company has seen a growth of productivity, which is good for both employees and the company itself and has brought in fresh air. (Story 36_M_second year)

The positive positioning of the male CEO and trust in him were therefore expressed when he was able not only to discipline, punish, allocate resources, and take strategic decisions but also to communicate with and support the employees - practices traditionally seen as more feminine than masculine. The results obtained therefore seem to gainsay role congruity theory (Eagly and Karau, 2002), according to which both men and women may be seen as behaving out of role when they 
perform certain management activities (Atwater et al., 2004). In our case, in fact, when men engage in roles stereotypically associated with feminine practices, such as supporting their employees, they are not viewed negatively; on the contrary, it is the only situation in which a completely positive evaluation is made of them. Also to be noted is that in the last vignette, by passing positive judgment on Davide's action, the narrator also mobilized the theme of diversity management in relation to migrant workers.

In the discussion of the features that define the image of "good management," the controversy centered on two questions. First, did Diana represent the image of the good manager and Davide that of the bad manager because the former expressed the hope that the presence of women in management will "make the difference," while the latter-a male and old-fashioned manager-embodied the distrust of young people in managerial capacities? Second, is good management inscribed in the activities and qualities of "care," and are these in their turn inscribed in a symbolism of gender? This discussion made it possible to introduce the theoretical concept of gendering practices and to show that the narratives had both discursively constructed the gender attributions of Diana and Davide and expressed implicit moral assumptions that constructed a positive moral judgment on the management when it concerned itself with issues such as communication, care-giving, and participation. A space for analysis and reflection thus arose between the gendering processes that attribute male or female characteristics to activities and people and the concept of gender as an individual property that attributes a gender to men and women.

In summary, as the third step in the discussion of the students' texts, we proposed the question of "how the positioning of the other was done and how the other (Davide or Diana) was constructed as a gendered manager." The vignettes that we chose to initiate the debate presented the gendering of management along the lines of instrumentality versus care and along a third gender positioning of the CEO as competent in both domains. The final controversial issue that we raised concerned the construction of goodness in management: whose goodness?

\section{Management for the good of the company or for the people in it?}

In some stories, the manager's lack of relational skills was not associated with a lack of business success. It was therefore kept distinct from the possession of good business abilities. In this case, the stories expressed disappointment in a managerial style which was uncaring and detached from the employees, but not necessarily negative for the company's productivity targets. These two stories stimulated reflection on whether management was to be evaluated only on performance measurements or on other indicators of "good management":

He's a serious person who has his goals firmly in mind. Unfortunately, however, too often they do not coincide with those of us workers. Although Tomasi has been able to work well in general management, to my mind he has been less successful in personnel management. By making so many lay-offs, he has clearly shown his strategy to cope with the crisis: reduce manning levels. [...] What Tomasi has done has been to protect the interests of the company, not those of the workers (as if these latter were not an integral part of the former). (Story 1_M_first years)

Diana Tomasi, my CEO, is a very talented person. Despite having a family to care about, when she is at work she leaves her problems at home and devotes herself entirely to her role as manager. She also gets very involved with personal problems. You can talk freely to her (always about work), asking for advice but also proposing new work methods. Conversely, when a decision is taken, she expects it to be strictly observed and if the job has to be performed by a given time, it is vital and imperative that the deadline is respected. (Story 40_W_second year) 
Note how in the latter narrative, in support of Diana's capacity to listen, employees' problems are prioritized over personal ones so that the female manager, despite having a family, is not conditioned by the latter in her dedication to work. This statement was open to different interpretations on how the relationship among work, gender, and family is constructed. It was widely discussed in relation to the controversial moral order sustaining loyalty to the firm versus loyalty to family in relation to a male or a female manager.

A similar discursive form, but of opposite sign, is expressed in the following extract, where the narrator expresses emotional endorsement of Diana's managerial style only after "passing a test":

The situation that most frightened me and made me fear for my job was when I proposed some changes to a project, and she examined my data and my analysis several times without ever explaining why. But when I started losing hope, my proposal was approved without smiles or compliments, but only with a blunt "yes." Whilst I initially I judged her behavior negatively, I've now learnt to appreciate her and to hold her in high regard. She is the boss and if she wants results at the end of the year, that is a winning strategy. (Story 33_W_second year)

An initially negative judgment subsequently becomes positive, and the sense of the story expresses a certain moral order where the results that Diana achieves represent the moral justification for a managerial style "without smiles or compliments." After the narrator (a woman) passes the test, she adopts a view that can be defined as realistic with respect to her initial expectation. This story illustrates a transition between the understanding and the expectations of someone who has just entered the world of work and adoption of an image that legitimizes what constitutes a winning strategy in terms of detachment from a "warm" relationship.

These extracts from the stories made it possible to start discussion with the students on the moral order sustaining the ideal of "good management," on how it may change in relation to their experience of organizational life, and on how - within the moral order expressed by the storiescontroversial issues were positioned and justified. Our aim was to lead the students back to their initial point in the debate and give them the opportunity to discuss what management is (for them), how they had "gendered" management practices, and how an idea of sustainable management can be elaborated starting from their critiques of "good and bad management."

\section{Discussion and conclusion}

One of the purposes of this article has been to discuss the potential of the constructive controversy approach in teaching strongly ideologized topics, for instance, the relationship between gender and management, but also the place of management in contemporary society. In fact, by eliciting opinions that will presumably be discordant, the approach enables students to discuss texts produced by themselves and to analyze them not only as expressions of individual points of view and opinions but also as historical and cultural products embedded and justified in socially available discourses. The result is that students become more closely involved than when they are asked to analyze preprepared case studies, which are often criticized by students as unrealistic. They are asked to engage in reflective thinking and critical learning.

In academic life, there are growing evidence of what has been called "gender fatigue," one aspect of which is a reluctance to acknowledge the persistence of gender inequities (Kelan, 2009b). Young women and men do not like to talk about gender as it seems outmoded and equality looks already achieved. As a consequence, gender is seen as an individual rather than a social problem and often disappears from sight (Meyerson and Fletcher, 2000). Therefore, in higher education and in gender and management education in particular, more subtle strategies are needed for gendering professional cultures and managerial education. 
Kelan and Jones (2010) identified several of those strategies:

such as teaching students that gender and diversity are at the core of the business and not optional extras, including male students and faculty in the change processes, making gender diverse role models more visible and creating support for informal networks in which the systemic nature of gender inequality can be voiced and specific incremental strategies for change can be developed. (p. 41)

Together with the suggestion provided by the previous authors, we wish to add the constructive controversy approach to the strategy of "small wins" (Weick, 1984) in order to promote an incremental change, which may gradually lead toward diversity inclusion without provoking a defensive and counterproductive response. There is thus a need to develop a plurality of methodologies for incorporating subtle forms of gender awareness into higher education.

Summarizing, the methodology that we have described-based on the constructive controversy approach - has the following advantages for the teaching of controversial themes:

- It fosters experiential and reflexive learning.

- It enhances the capacity to listen to opposing ideas and respect them.

- It teaches how an issue can be discussed from different standpoints.

- It facilitates personal involvement in the topics proposed while teaching how to theorize starting from personal opinions.

Moreover, because the method aims to transcend the individual story and invites consideration of its situated context of production, it is also an interesting method for researching the historicity of the social representations of controversial issues.

Diversity is a topic increasingly taught in business schools (Hazen and Higby, 2005), and the latter have a particular interest in understanding how to teach sensible issues, but the same interest lays at the core of higher education as well. Nevertheless, a pedagogy for teaching inclusion and diversity is not yet fully developed (Kelan and Jones, 2010), and it is much needed since discussions about diversity are often driven by the fear of saying something wrong and offensive (Ely et al., 2006).

In the students' narratives we have analyzed, we saw — and we expected to see - institutionalized expectations of gender difference in workplaces and the discursive negotiation of "reasonable" gender performances; emphasis on a model of rationality defined against emotionality; and the assumption of gender differences in communication, habits, and skills. What was unexpected in the stories was the strongly negative evaluation that the male CEO received and the distrust expressed in his managerial style. A contextual feature, that is, the fact that the stories were collected at a time when the economic crisis discourse was so pervasive and also when the political climate in Italy was so unfavorable to what Berlusconi represented as a manager and as a man, should be considered a cultural factor shaping the context in which the stories were told, even when it was not directly represented in the narrative. Likewise unexpected was the positioning of the female CEO as trustworthy because of her ability to create a good work environment. We may therefore say that distrust in the male management style and trust in the female one can also be interpreted as the effects of the context. This point is worthy of further investigation since the social consideration of management may have changed in relation to actual managerial performances so that also the gendered construction of management may be influenced by the economic crisis.

In fact, the moral order expressed in the students' narratives through the positioning of "the good management" was constructed by mobilizing both "soft" competences and "hard" results. The justification work that they performed in discussing the controversies leads to a more nuanced understanding of gender and management. 
Good management was inscribed in the realm of care, that is, within a female symbolic order. Although we cannot claim that Davide's performance was explicitly positioned as "the cause" of the economic crisis, the co-occurrence of the two terms is surprising. On the other hand, the positive image of what constitutes "good management" was justified with the same discursive elements whether the CEO was Davide or Diana. The narratives of the sociology students positioned "good management" in relation to "soft" socio-communicative competences (a good work climate, participation, manager's communicative style, attention to safety) rather than "hard" elements like good results, profit, or stakeholder satisfaction. And vice versa, the negative positioning of Davide or Diana was constructed by the absence of the same elements.

Our study contributes to a critical feminist reading of gender and management by illustrating the positioning of masculinity and femininity in relation to what constitutes "good management" in the imaginations of young students entering a labor market characterized by precarity and the highest rate of youth unemployment of the past 30 years. We believe that distrust in management and the inscription of "good management" in the realm of care warrant investigation outside the student population and the Italian context because they may represent how legitimation of the traditional managerial style is changing under the present economic crisis.

Within a wider societal context, we have to consider how business and management cultures are strongly gendered masculine, making it difficult for women to fit into the prevailing culture. In particular, MBA education is still fundamentally masculine (Simpson, 2006), but could be reshaped and feminized, at a time when the effectiveness of business education is increasingly under scrutiny (McCabe et al., 2006). In fact, the "think management, think male" paradigm is slowly shaking (Gherardi and Murgia, in press), and the many cases of bad management or sloppy management style that the media present have prompted awareness to the need to rethink the ethical dimension of management accountability. Therefore, it seems vital to include a perspective on gender and business ethics when configuring managerial education for the next generation of professionals and managers, given that gender diversity is a factor in the ranking of business and that many institutions are attempting to improve recruitment within female students and male students who are open minded toward diversity management.

A final consideration concerns the limitations of this study. While on the one hand it is interesting to analyze students' talk as an opportune space in which to explore subject formation processes, in general, and, in particular, those regarding gendered interpretations of management, on the other, it is necessary to bear the context in which the narratives are collected in mind. A class is always a context of interaction structured by a power asymmetry, and the teachers unconsciously structure this context because their personal convictions concerning gender and management transpire even when they are not explicitly expressed. Finally, in conducting the discussion and in furnishing the text analysis methodology, the context of the controversies that are discussed (or not discussed) is somehow directed by the teachers. Different teachers or different students may produce different results. Nevertheless, since the aim of a constructed controversial approach is to promote debate and reflective thinking, we offer the vignettes that our students produced and we tested in class for further use by other teachers in different contexts. One practical result of our teaching experiment is that the vignettes that our students produced can be used as teaching materials in different contexts.

\section{Acknowledgements}

We wish to thank Saija Katila and Päivi Eriksson for their encouragement and comments on earlier versions of the article. The present article is the outcome of joint and indivisible work by the authors; however, if for academic reasons individual authorship is to be assigned, Gherardi wrote the theoretical part, the study design and the conclusion, and Murgia wrote the introduction and the empirical part. 


\section{Funding}

This research received no specific grant from any funding agency in the public, commercial, or not-for-profit sectors.

\section{Note}

1. We asked the students whether they were interested in trying out a narrative methodology. We explained that it was not part of the course program and that it would not be assessed in the final examination. Because not everyone likes writing free texts, we preferred to make participation voluntary. We were obviously aware of the asymmetric power relation that restricts the freedom of expression.

\section{References}

Alcoff L (1988) Cultural feminism versus post-structuralism: The identity crisis in feminist theory. Signs 13(3): 405-436.

Alvesson M and Deetz S (2000) Doing Critical Management Research. London: SAGE.

Alvesson M, Bridgman T and Willmott H (2009) The Oxford Handbook of Critical Management Studies. Oxford: Oxford University Press.

Ashcraft KL (2011) Gender and diversity: Other ways of making a difference. In: Alvesson M, Bridgman T and Willmott H (eds) The Oxford Handbook of Critical Management Studies. Oxford: Oxford University Press, 304-327.

Atwater LE, Brett JF, Waldman D, et al. (2004) Men's and women's perceptions of the gender typing of management subroles. Sex Roles 50(3-4): 191-199.

Bauer MW and Gaskell G (eds) (2000) Qualitative Researching with Text, Image and Sound: A Practical Handbook. London: SAGE.

Bird SR and Erickson KA (2010) A constructive controversy approach to "Case Studies." Teaching Sociology 38(2): 119-131.

Boltanski L and Thévenot L (2000) The reality of moral expectations: A sociology of situated judgment. Philosophical Explorations: An International Journal for the Philosophy of Mind and Action 3: 208-231.

Boltanski L and Thévenot L (2006 [1991]) On Justification: Economies of Worth. Princeton, NJ: Princeton University Press.

Bombelli MC (2000) Soffitto di vetro e dintorni. Il management al femminile. Milano: Etas.

Calás MB and Smircich L (2009) Feminist perspectives on gender in organizational research: What is and is yet to be. In: Buchanan D and Bryman A (eds) The Handbook of Organizational Research Models. London: SAGE, 246-269.

Calás MB, Smircich L and Holvino E (2014) Theorizing Gender-and-Organization: Changing Times, Changing Theories. In: Kumra S, Simpson R and Burke R (eds) The Oxford Handbook of Gender in Organizations. London: Oxford University Press, 17-52.

Collinson D and Hearn J (1994) Naming men as men: Implications for work, organization and management. Gender Work and Organization 1(1): 2-22.

Connell R (1987) Gender and Power: Society, the Person and Sexual Politics. Cambridge: Polity Press.

Davies B and Harré R (1990) Positioning: The discursive production of selves. Journal for the Theory of Social Behavior 20(1): 43-63.

Diaz-Bone R (2011) The methodological standpoint of the "économie des conventions." Historical Social Research 36(4): 43-63.

Dodier N (1993) Review article: Action as a combination of "common worlds." Sociological Review 41: $556-571$.

Douglas M (1975) Implicit Meanings: Essays in Anthropology. London; Boston, MA: Routledge and Kegan Paul.

Eagly A and Karau S (2002) Role congruity theory of prejudice toward female leaders. Psychological Review 109: 573-598.

Ely RJ, Meyerson DA and Davidson MN (2006) Rethinking Political Correctness. Harvard Business Review 84(9): 78-87. 
Fletcher JK (2004) The paradox of postheroic leadership: An essay on gender, power, and transformational change. Leadership Quarterly 15: 647-661.

Gherardi S (1995) Gender, Symbolism and Organizational Cultures. London: SAGE.

Brown A, Gabriel YS and Gherardi S (2009) Storytelling and Change: an Unfolding Story. Organization 16(3): 323-334.

Gherardi S and Murgia A (in press) Narratives of gender and 'good management'. Equality, Diversity and Inclusion.

Grey C and Willmott HC (2005) Critical Management Studies: A Reader. Oxford: Oxford University Press.

Hazen MA and Higby MA (2005) Teaching an issues-based interdisciplinary course: Diversity in management and marketing. Journal of Management Education 29(3): 403-427.

Jagd S (2011) Pragmatic sociology and competing orders of worth in organizations. European Journal of Social Theory 14: 343-359.

Katila S and Eriksson P (2013) He is a firm, strong-minded and empowering leader, but is she? Gendered positioning of female and male CEOs. Gender Work and Organization 20(1): 71-84.

Kelan EK (2009a) Performing Gender at Work. Basingstoke: Palgrave Macmillan.

Kelan EK (2009b) Gender fatigue-The ideological dilemma of gender neutrality and discrimination in organizations. Canadian Journal of Administrative Sciences 26(3): 197-210.

Kelan EK (2013) The becoming of business bodies: Gender, appearance, and leadership development. Management Learning 44(1): 45-61.

Kelan EK and Jones R (2010) Gender and the MBA. Academy of Management Learning \& Education 9(1): 26-43.

Knights D and Kerfoot D (2004) Between representations and subjectivity: Gender binaries and the politics of organizational transformation. Gender Work and Organization 11(4): 430-454.

Kociatkiewicz J and Kostera M (2012) The good manager: An archetypical quest for morally sustainable leadership. Organization Studies 33(7): 861-878.

McCabe DL, Butterfield KD and Trevino LK (2006) Academic dishonesty in graduate business programs: Prevalence, causes, and proposed action. Academy of Management Learning \& Education 5(3): 294-305.

Martin J and Meyerson D (1997) Women and power: Conformity, resistance, and disorganized co-action. In: Kramer R and Neale R (eds) Social Influence in Organizations. Newbury Park: SAGE, 311-348.

Martin PY (1996) Gendering and evaluating dynamics: Men, masculinities and managements. In: Collinson DL and Hearn J (eds) Men as Managers, Managers as Men. London: SAGE, 186-209.

Martin PY (2001) "Mobilizing masculinities”: Women's experiences of men at work. Organization 8: $587-$ 618.

Martin PY (2003) "Said and done" vs. "saying and doing": Gendering practices, practicing gender at work. Gender \& Society 17(4): 342-366.

Martin PY (2006) Practising gender at work: Further thoughts on reflexivity. Gender Work and Organization 13(3): 254-276.

Meyerson DE and Fletcher JK (2000) A modest manifesto for shattering the glass ceiling. Harvard Business Review 78(1): 126-136.

Murgia A and Poggio B (2011) Sotto il tetto di cristallo: scenari, cause e strategie per infrangerlo. Dialoghi Internazionali 15: 75-81.

Murgia A and Poggio B (2014) Moving societies and immobile organizational practices. The winding road of diversity management in Italy. In: Klarsfeld A et al. (eds) International Handbook on Diversity Management at Work - Second Edition. Cheltenham: Edward Elgar, 123-136.

Patriotta G, Gond JP and Schultz F (2011) Maintaining legitimacy: Controversies, orders of worth, and public justifications. Journal of Management Studies 48(8): 1804-1835.

Pernkopf-Konhäusner K (2014) The competent actor: Bridging institutional logics and French pragmatist sociology. Journal of Management Inquiry 23(3): 333-337.

Poggio B (2006) Outline of a theory of gender practice. Gender Work and Organization 13(3): 232-233.

Potter J (1996) Representing Reality: Discourse, Rhetoric and Social Construction. London: SAGE.

Schein VE (2007) Women in management: Reflections and projections. Women in Management Review 22(1): 6-18. 
Short KG, Schroeder J, Laird J, et al. (1996) Learning Together Through Inquiry: From Columbus to Integrated Curriculum. Portland, ME: Stenhouse Publishers.

Simpson R (2006) Masculinity and management education: Feminizing the MBA. Academy of Management Learning \& Education 5(2): 182-193.

Sinclair A (2000) Teaching managers about masculinities. Management Learning 31(1): 83-101.

Sinclair A (2005) Body possibilities in leadership. Leadership 1: 387-406.

Törrönen J (2002) Semiotic theory on qualitative interviewing using stimulus texts. Qualitative Research 2: $343-362$.

Vinnicombe S (2000) The position of women in management in Europe. In: Davidson MJ and Burke RJ (eds) Women in Management: Current Research Issues. London: SAGE, 9-25.

Weick KE (1984) Small wins: Redefining the scale of social problems. American Psychologist 39(1): 40-49. 